\title{
The Effect of Electronic Procurement on the Performance of Car Parts Supply Chain Companies
}

\author{
Reyhaneh Toudeh Bahambari ${ }^{1}$ and Hamidreza Rezaee Kelidbari ${ }^{2}$
}

${ }^{1}$ MA Business Management, (International Business), Rasht Branch Islamic Azad University, Rasht, Iran. ${ }^{2}$ Department of Management, Rasht Branch, Islamic Azad University, Rasht, Iran.

DOI: http://dx.doi.org/10.13005/bbra/1958

(Received: 08 September 2015; accepted: 18 October 2015)

\begin{abstract}
Companies have to improve their procedures in order to have an increase in their performances. One the most important and most costly activities in companies which causes a great deal of official expenses for the companies is procurement procedure. Therefore, the aim of this study was to investigate the role of e procurement via supply chain integration on the performance of supply chain. The current study was done on sapco car parts production companies which have grade a in their products. This study is a descriptive-correlational study. The sample under investigation have been selected through non-random sampling. The data gathered in this study via chang et al (2013) questionnaire. In order to test the hypothesis, structural equation modeling has been used. The result of this research showed that e procurement has an effective role in improvement of performance of supply chains under investigation.
\end{abstract}

Key words: Electronic Procurement, Supply Chain Performance, Supply Chain Integration.

In the competitive current trade world, the people who give logistic services regarding the supply process of companies have a crucial role in improvement of performance of the companies (jothimani \& sarmah,2014,p:944). This emphasis on the abilities of supply chains and also outsourcing has led more companies to rely on other sources to improve their performance and also to decrease the value of their services (huo et $a l, 2014, p: 369)$. In order to get close to developing markets or newlyfound markets and also in order to decrease different expenses, a lot of companies, have assigned a great deal of their value added processes to the supplier with lower costs. Concentration on companies will facilitate

\footnotetext{
* To whom all correspondence should be addressed.
}

understanding, design and commercial use of any products in the companies (schaltegger \& burritt,2014,p:232). Normally the performance of a business is evaluated traditionally and the first criteria is financial index for example the return of investment and the pure benefit (ou \& et al, 2010,p:532).

In the current study, supply chain integration has been considered as an effective factor on the performance of supply chain when applying e procurement. And based on the issues discussed above the research question under investigation is as follow:

Is e procurement effective on the performance of the supply chain?

\section{Theoretical Framework}

In this research the effect of e procurement via supply chain integration on the performance of supply chain have been investigated based on the figure below: 


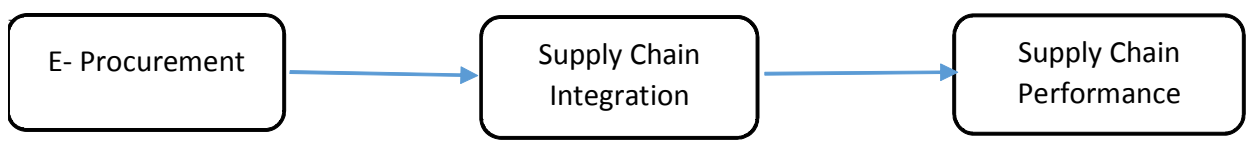

Fig. 1. Conceptual Model (Chang Et Al, 2013, P: 33)

E-procurement have been considered as the main variable in the current study for two main reasons:

Firstly, companies have to improve their internal procedures in order to improve their general performance. One of the main activities which causes a lot of official and non-official expenses is the process of procurement (Zunk \& et al, 2014, p: 13). E procurement system can be effective on the activities of the supply chain and can it can also increase transparency in supply chain. Therefore, it can be shown that e procurement system is more applicable than other plans in electronic trade (Chang et al, 2013, p: 35).

Secondly, in the current economic situation, value is an important factor in improvement of supply chain. It can be expected that the practical features of e procurement system makes the company able to improve the procedures of making value in supply chain (Chang et al, 2013, p: 35). E procurement is a digital sub structure used to integrate, improve and simplify procurement procedures in companies and organizations (Barahona, 2014, p: 2). E procurement is defined as a technological solution which facilitates purchase and procurement procedures in companies (Piera et al, 2014, p: 9)..

E procurement shows the ability to use ecommerce in order to protect and support organization's procurement activities (Mahbubur, 2014, p: 2). In this study e procurement is defined as an online shopping system with four parts: Electronic planning, electronic resources, electronic negotiation, and electronic evaluation (Chang et al, 2013, p: 35). Electronic planning is about adjusting shopping needs in electronic procurement. Electronic resourcing is defined as the procedure of selection of suppliers in electronic procurement. Electronic negotiation is defined as different types of negotiations and preparing contracts via electronic technology. And electronic evaluation is the final step in which a lot of information about suppliers is gathered and should be evaluated in more details (Omai, 2013,p:405).
One of the outcomes of attention to electronic procurement is the improvement of the performance of supply chain. In the newest definition of performance of supply chain, it is defined as "the ability of the organization in satisfying end customer from quality and expenses." (Written, 2012, p:32) the performance of supply chain regarding management of supply chain has hidden and observable dimension in which observable dimensions are cost and benefit and hidden dimensions are using different type of organization capacity, the quality of the products, and customer satisfaction(chang et al,2013,p:35).

In this study, in which the performance of e procurement on supply chain is investigated, integration has a mediation role. Companies can use different ways to find out sources. Between these ways, integration is the most important one (sabidussi et al, 2014, p: 19). Integration of supply chain in a systematic manner leads to harmony in resources and facilities of each partner in supply chain in order to increase performance in decrease total expenses (huang, 2014, p: 66). Integration is the extent to which a company has strategic cooperation with its partners in inside and outside company procedures (mackelprang et al, 2014, p: 72). The application of electronic procurement in the structure of supply chain integration (sci) via improvement of speed and potential precision of communication in all available networks in the chain, causes improvement in performance and a better harmony in the activities (omai, 2013, p: 408).

Electronic procurement with integration of supply chain has some reasons: Electronic procurement systems can prepare chances for investment in order to be in accordance with company's partners. As an example, previous researches have shown that with information technology we can improve joint planning. It means that cooperation between the company and its partners can improve significantly through electronic procurement. So it is expected that integration of supply chain can improve via use of electronic procurement (Chang et al, 2013, p: 36). 
It was shown both in researches and in practice that harmony and integration of activities in entire supply chain are key strategies for improvement of performance, access and competition advantage (Mackelprang et al, 2014, p: 71). Integration of supply chain whose aim is creation of seamlessness in supply chain through coordination between information flow and material is an important factor in accessing to acceptable performance (Danese, 2013, p: 1029).

Now considering the relation between variables and the presented model for the study, the hypothesis of the study are presented as follow:

1. Employing electronic procurement is effective on integration of supply chain.

2. Integration of supply chain has a significant Methodology impact of performance of supply chain.

The current study is a descriptive correlational study. The population of this study are 81 companies. These companies are car parts production companies with a grade a. In sampling for this research as the unit of analysis is this study is organization, in the first phase, census has been used so that all companies in the population (81 companies) are considered as sample. And in the second phase, nonrandom judgmental sampling has been used. In this phase for all companies under investigation between 3 to 5 questionnaire have been sent (altogether 330) and finally 215 questionnaire have been gathered for data analysis. In order to collect the required data regarding the investigation of the research question field data gathering has been used. In the current research chang et al questionnaire has been used to collect data from factory managers, presidents of factories, trade center experts, quality control managers of in car parts production industry.

In this questionnaire there are 39 questions in which the performance of supply chain as a dependent variable with 15 questions, electronic procurement with 15 questions and integration of supply chain with 9 question in which the questions are closed, are discussed. In this questionnaire, the answers are classified based on likert scale from completely agree to completely disagree. This questionnaire was validated by a group of experts. The reliability of this questionnaire has been calculated through cronbach alpha as 0.892 for questions regarding performance of supply chain, 0.9 for questions regarding electronic procurement, and 0.87 for questions regarding integration of supply chain. These calculation shows that this questionnaire has a high level of reliability. It means the results obtained from it is not accidental and is indicative of the variable under investigation.

\section{Findings}

In this section, the variables of the research are analyzed through calculation of mean and standard deviation in order to be able to make a general view of the variables under investigation. It is observed that variables are above average. As likert scale has five choices, it was observed that all variables are above average. It means more than three.

\begin{tabular}{lllllll}
\hline Variance & SD & Mean & Max & Min & No. & Descriptive Statistics \\
\hline 0.67 & 0.82 & 3.7942 & 5 & 1.83 & 81 & Supply Chain Performance \\
0.62 & 0.79 & 3.7499 & 5 & 1.74 & 81 & E-Procurement \\
0.54 & 0.73 & 3.7496 & 5 & 2.08 & 81 & Supply Chain Integration \\
\hline
\end{tabular}

In order to do the data analysis and test the hypothesis of the study, structural equation modeling has been used. The first step is to analyze the normality of the variables using colmogrophsmirinoph. Considering that meaningful level of research variables is more than $50 \%$ we can conclude that variables in the research has normal distribution. So we can use parametric method. Now we can analyze the hypothesis of the study:
Considering the data in the model which is meaningful, we can infer that the relationship between the variables of the research is meaningful and we can use them to accept or reject the hypotheses. In this research as the confidence level is 0.95 and error probability is 0.05 , the acceptable $t$ retrieved from the $t$ test should be out of the interval between -1.96 to 1.96 . It means if $t$ is between -1.96 to 1.96 , it is meaningless. 


$\begin{array}{cccccccc}\text { IFI } & \text { CFI } & \text { NFI } & \text { NNFI } & \text { GFI } & \frac{\chi^{2}}{d_{f}} & \text { RMSEA } & \text { Index } \\ 0.98 & 0.98 & 0.92 & 0.97 & 0.89 & 1.35 & 0.064 & \text { Quantity } \\ & & & & & & & \text { Desired } \\ 0 / 8 \leq \& \leq 1 & 0 / 8 \leq \& \leq 1 & 0 / 8 \leq \& \leq 1 & 0 / 8 \leq \& \leq 1 & 0 / 8 \leq \& \leq 1 & 0 \leq \& \leq 5 & 0 \leq \& \leq 0 / 1 & \text { Form }\end{array}$

Also considering the output of soft wares, standard predictions and meaningful numbers , the result of indirect effect of variables is presented in table below:

$(0 / 38)(0 / 59)$ E-Procurement $\rightarrow$ Integration $\rightarrow$ Performance
$=(0 / 22)$
$(2 / 02)(3 / 85)=(7 / 77)$
$\quad$ considering the results obtained from structural equations, acceptance or rejection of the

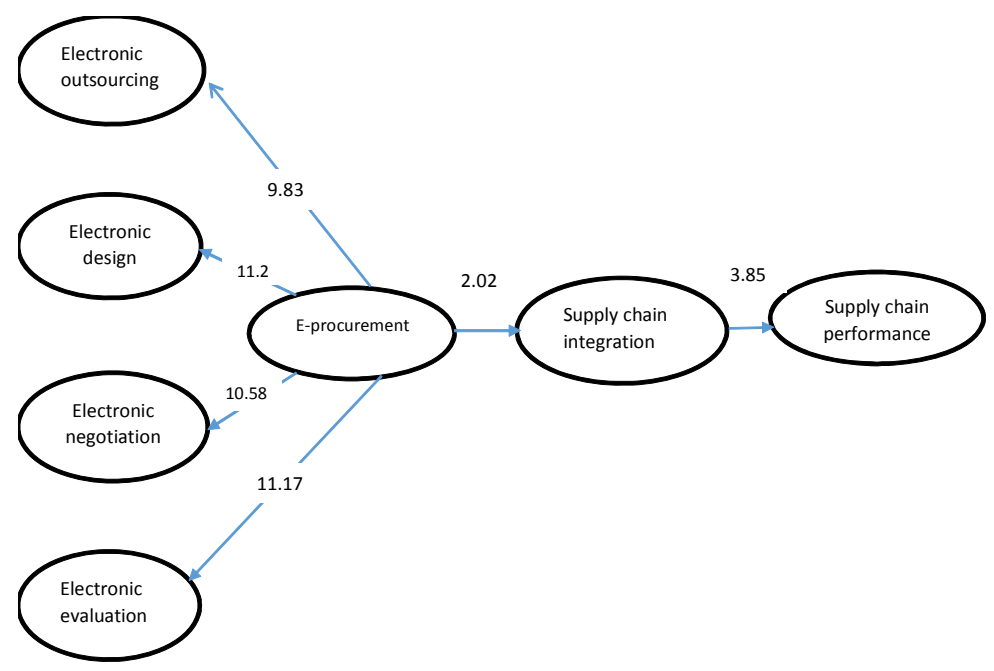

Fig. 2. The Basic model of the study

\begin{tabular}{llcl}
\hline Results & T & Correlation & Research Hypothesis \\
\hline Accept & 2.2 & 0.38 & Using Electronic Procurement Has A Positive Effect On Supply Chain Integration \\
Accept & 3.85 & 0.63 & Supply Chain Integration Has A Positive Effect Of Supply Chain Performance \\
\hline
\end{tabular}

hypotheses of the research is presented in table 4 . as can be seen, considering the value of $t$ both of the hypotheses of the research are accepted.

\section{RESULTSAND DISCUSSIONS}

The result of the investigation in this research has shown that using electronic procurement leads to increase of positive results in integration in different parties of supply chains. Also integration in supply chain leads improvement in performance of supply chain. Considering the results of previous researches one can conclude that employing electronic procurement system has a direct positive effect on the performance of supply chain. (It means it can reduces the costs and help to provide input resources in production systems) (Chang et al 2013, Barahona 2014, Zunk et al 2014, Latif 2014) .in order to improve the performance of supply chains, they can be asked to use electronic systems more. These electronic systems include internet, intranet (inside organization). They can use electronic system to publish their enquiries such as material and other things. They can also 
share different information regarding their business with their partners.

Considering the direct effect of integration on improvement of performance of supply chain which is in accordance with the results obtained from the study of (Mackelprang et al 2014, Chang et al 2013, Danese 2013, Zhao et al 2013 and Lee et al 2007), it is suggested to organizations to improve integration inside their organization. They can do so with gathering working teams. In order to promote outer integration they can use special plans such as crm, etc. In order to be in more harmony and accordance with other business partners.

At the end it is necessary to note that the current research has just investigated the effect of electronic procurement system on supply chain. In future researches other practical programs such as w-auction and virtual communities can be investigated. It is also needed to be mentioned that this research has been done on car parts production and the results cannot be overgeneralized to other fields. Also this research just included downstream (supplier of initiative material). The effect of different strategies of supply chain hasn't been considered in this research. Prospective researcher can investigate this issue in other industries such as food industry, medicine and so on. They can consider all members of supply chain and distributers. The last suggestion for further research in this regard is the investigation of effects of different strategies of supply chain on performance of supply chain using performance evaluation tools such as balanced score card (BSC) or scor model.

\section{REFERENCES}

1. Barahona Juan Carlos, Elizondo Andrey, "Introducing A Disruptive Service Innovation: A National Dilemma In E-Procurement”, Management Decision, 2014; 9: 1-38

2. Chang Hsin Hsin, Tsia Yao-Chuan,Hsu Che-Hao, E-Procurement And Supply Chain Performance, Supply Chain Management: An International Journal , 2013; 1 : 34-51

3. Danese Pamela, Supplier Integration And Company Performance: A Configurational View, Omega, 2013; 41: 1029-1041

4. Huang Ming-Chang, Yen Ghi-Feng, Liu TzuChuan, Reexamining Supply Chain Integration
And The Supplier's Performance Relationships Under Uncertainty”, Supply Chain Management:, Emerald Group Publishing Limited, 2014; 1: 64-78

5. Huo Baofeng, Zhiqiang Yinan, Wang Qi, Zhao Xiande, "The Impact Of Supply Chain Integration On Firm Performance", Supply Chain Management: An International Journal, 2014; 4: 369-384

6. Jothimani Dhanya, Sarmah S.P. ,"Supply Chain Performance Measurement For Third Party Logistics”, Benchmarking: An International Journal, 2014; 6: 944 -963

7. Mackelprang Alan W., Robinson Jessica L., Bernardes Ednilson, Webb G. Scott, The Relationship Between Strategic Supply Chain Integration And Performance: A Meta-Analytic Evaluation And Implications For Supply Chain Management Research, Journal Of Business Logistics, 2014; 1: 71-96

8. Mahbubur Rahim Md., Kurnia Sherah,, Understanding E-Procurement System Benefits Using Organizational Adoption Motivation Lens, A Case Study. Association For Information Systems, AIS Electronic Library (Aisel), PACIS 2014 Proceedings. 2014; 80.Pp:2-13

9. Omai Kevin Moindi, Determinants Of Electronic Procurement On Supply Chain Performance: A Survey Of Tea Factories In Kisii County-Kenya Interdisciplinary Journal Of Contemporary Research In Business, 2013; 12: 399-425

10. Ou Chin S., Liu Fang C., Hung Yu C., Yen David C., A Structural Model Of Supply Chain Management On Firm Performance, International Journal of Operations \& Production Management, 2010; 5: 526-545

11. Piera Centobelli, Robertob Cerchione, Giuseppea Converso, Teresaa Murino, E-Procurement And E-Supply Chain: Features And Development Of E-Collaboration IERI Procedia, 2014; 6: 8 14

12. Sabidussi Anna , Timdeleeuw Borislokshin, Harrybremmers Geert Duysters, , Omta Onno, Comparative Perspective On External Technology Sourcing Modalities: The Role Of Synergies, Journal of Engineering And Technology Management, 2014; 33: 18-31

13. Schaltegger Stefan, Burritt Roger, "Measuring And Managing Sustainability Performance Of Supply Chains”, Supply Chain Management: An International Journal, 2014; 19(3): 232-241

14. Written G. Dwayne, Green Jr Kenneth W., Zelbst Pamela J., Triple-A Supply Chain Performance, International Journal of Operations \& Production Management ,2012; 1: 28-48. 
15. Zunk Bernd Markus, Marchner Martin Johannes, Uitz Iris, Lerch Carina, Schiele Holger, The Role Of E-Procurement In The Austrian Construction Industry: Adoption Rate, Benefits
And Barriers, International Journal Of Industrial Engineering And Management (IJIEM), 2014; 1: 13-21. 